\title{
Does compliance with corporate governance codes help to mitigate financial distress?
}

\author{
Francisco Bravo-Urquiza *, Elena Moreno-Ureba \\ Departamento de Contabilidad y Economía Financiera, Universidad de Sevilla, Avd. Ramón y Cajal 1, 41018, Sevilla, Spain
}

\section{A R T I C L E I N F O}

\section{JEL classification:}

G33

G34

\section{Keywords:}

Corporate governance codes

Corporate governance

Financial distress

Board of directors

Board subcommittees

\begin{abstract}
A B S T R A C T
This paper analyzes whether the compliance with corporate governance codes helps to mitigate the financial distress of firms. We examine three different levels of compliance: overall compliance, the compliance with the recommendations regarding the board of directors and the compliance with the recommendations on board subcommittees. Our results reveal that only the fulfillment with the recommendations about the board of directors leads to a reduction in the likelihood of financial distress. These findings extend the academic debate concerning the role of governance codes and their impact on firm outcomes, and have practical implications for both professionals and firms. Moreover, our findings emphasize the need to distinguish between the different types of recommendations to investigate the effects of these codes. In addition, the results can be useful for policymakers in the configuration of new requirements and recommendations regarding corporate governance structures. Furthermore, our results contribute to the literature, delving into the determinants of the financial distress of firms.
\end{abstract}

\section{Introduction}

The succession of the corporate scandals all over the world and the recent global financial crisis has stressed deficiencies in governance mechanisms, which have had severe consequences in capital markets. Accordingly, the number of corporate governance codes (CGC, hereinafter) has increased exponentially over the last years. Indeed, most developed countries have recently introduced CGC and, consequently, researchers have paid a great deal of attention to investigating the effects of their compliance. The main objective of this paper is to analyze whether the compliance with CGC may help to mitigate the financial distress of firms. This topic is timely and relevant due to the ongoing debates about both the effects of CGC compliance and the determinants of financial distress.

On the one hand, the adoption and the repercussion of these codes has become a societal concern. Consequently, scholars, public opinion, and politicians have pushed legislators and the professional bodies to reinforce governance codes in order to increase internal control and accountability (Cuomo et al., 2016). These CGC are based on recommendations about governance mechanisms and have gained increased visibility and importance in capital markets for investors and regulators (Cicon et al., 2012). Although the compliance levels are generally high, the majority of the firms fail to fully comply with all the codes recommendations because the effects of the CGC compliance remain largely unexplored (Kabbach de Castro et al., 2017). Previous research has investigated whether there is an economic rationale behind the compliance with CGC recommendations or if this is only an ethical issue for social legitimacy reasons. In this regard, a few studies suggest that the CGC compliance leads to positive market reactions by increasing the market value

\footnotetext{
* Corresponding author.

E-mail addresses: pacobravo@us.es (F. Bravo-Urquiza), elenamoreno103@hotmail.com (E. Moreno-Ureba).
} 
(Goncharov et al., 2006; Kaspereit et al., 2017) and corporate reputation (Hooghiemstra and van Ees, 2011). Another branch of research argues that CGC compliance may positively impact on major corporate strategic decisions and help to improve firm performance (Stiglbauer, 2010). However, research on the effectiveness of CGC is scarce, and there are still important gaps in the literature which calls for new research on the potential benefits of CGC compliance. In this sense, recent research has highlighted the need to provide a more careful examination of the codes' content and to further explore the relationship between codes compliance and other firm financial outcomes (Cuomo et al., 2016). We extend the previous literature by filling in both research gaps. First, this paper makes an in-depth analysis of CGC since we focus on three different levels of compliance. To that end, we consider the overall compliance of CGC, like previous studies, and additionally we also take into account the compliance with the recommendations about the board of directors and about the board subcommittees, which is one of the novelties of this study. Second, our paper focuses on an important firm outcome in the literature on business and finance, such as the financial distress of companies, which will provide a better insight about the effects of CGC compliance.

On the other hand, the debate about the determinants of financial distress has sparked interest since several decades ago and especially after the last financial crisis because of the important consequences on all the stakeholders of a firm (Mselmi et al., 2017; Boubaker et al., 2018). The previous research has highlighted the complexity of predicting firms` financial distress situations for the agencies' credit ratings, governments or financial creditors and has emphasized the role of corporate governance mechanisms to prevent business failure (Manzaneque et al., 2016a). An implicit premise to explain this potential association is that corporate governance is expected to have important implications for corporate decisions, especially when the business has a high risk of failure (Dowell et al., 2011). In this sense, the nature of the association between the corporate governance mechanisms and the likelihood of financial distress has been discussed among researchers and policy-makers alike, and the role of corporate governance in mitigating financial distress remains a core issue nowadays, after the financial crisis and financial scandals of important companies around the world (Manzaneque et al., 2016b; Udin et al., 2017). However, the literature that deals with the association between corporate governance and the likelihood of firms' financial distress is limited and lacks investigating the impact of CGC compliance. In theory, the final objective of CGC is to recommend best governance practices in order to mitigate agency conflicts, thereby protecting shareholders' interests and ensuring business prosperity.

Our sample is composed of companies in the Spanish IBEX35 index for the period 2013-2016. The particular characteristics of Spanish firms, such as high ownership concentration, a unitary board system and voluntary good governance practices, are likely to lead to significant agency conflicts driven by a majority-minority conflict (Manzaneque et al., 2016a; Bona-Sánchez et al., 2018). Therefore, the study of the Spanish context offers an interesting scenario to analyze the effect of corporate governance on the likelihood of financial distress. Our results highlight that the likelihood of financial distress is only reduced when the compliance of the recommendations on boards of directors is high. Nevertheless, we fail to find any relationship between the probability of financial distress and both the overall compliance of CGC recommendations and the specific compliance of board subcommittees' recommendations. These findings contribute to the business and finance literature in several ways. First, our evidence stimulates the debate about the effectiveness of CGC compliance in corporate decisions and helps to explain whether the compliance of the recommendations contained in CGC is a moral issue or a business case. Second, we suggest that a detailed analysis of CGC content is required to better comprehend the effectiveness of CGC. In particular, a one-size-fits-all approach may be inappropriate to understand the role of the CGC since our results show that not all the types of recommendations seem to be effective to mitigate financial distress. The analysis of the CGC based on three different levels of compliance is a new issue in the literature and therefore we expect to contribute to the current research by providing new measures concerning CGC compliance and refining the ongoing debates regarding the consequences of the application of CGC. Finally, this study also attempts to help business failure literature by predicting that some corporate governance structures may help companies to avoid failure. In particular, we complement the literature on the determinants of financial distress by shedding some light on how the compliance of CGC may reduce the likelihood of financial distress.

The paper is organized as follows. The literature review and the hypothesis development are provided in Section 2 . Section 3 describes the data collection process and the sample, and explains the research method. Section 4 discusses the results of the empirical analysis and Section 5 summarizes the contributions of the paper.

\section{Literature review}

The empirical debate regarding the determinants of financial distress focused on financial and accounting information many decades ago (Altman, 1968; Beaver, 1966; Zmijewski, 1984). Nevertheless, more recent research suggests that economic and financial data alone lacks sufficient predictive power for the prediction of financial distress (Chang, 2009; Fich and Slezak, 2008). In particular, a number of studies have pointed out that variables related to corporate governance structures must be taken into consideration in order to better understand the determinants of financial distress (Habib et al., 2020). Yet, the majority of these studies tend to examine specific corporate governance characteristics. In this regard, some studies find that companies with higher board independence and CEO duality are less likely to have financial distress (Salloum et al., 2013; Baklouti et al., 2016). Other studies have examined the relationship between board size and the likelihood of financial distress, although the evidence found is mixed (Fich and Slezak, 2008; Manzaneque et al., 2016a). Parker et al. (2002) found a negative significant association between the replacement of the CEO and the likelihood of firm survival. Moreover, Shahwan (2015) considered certain items related to shareholders' rights and relationship with investors as potential drivers of financial distress. Several papers have also focused on ownership structure as a relevant corporate governance mechanism. For instance, the likelihood of corporate failure has been negatively associated with ownership concentration and state ownership (Li et al., 2008), with institutional ownership (Manzaneque et al., 2016b; Udin et al., 2017) and with board ownership (Abdullah, 2006). Although the majority of these studies have used corporate governance characteristics individually, the 
recent literature also calls for the need to employ composite measures, which aggregates a number of governance indicators considering the interaction between multiple corporate governance mechanisms, to provide a better overview of the effectiveness of corporate governance structures (Brown et al., 2011; Jain and Jamali, 2016; Bravo et al., 2018). Consistent with this approach, our paper focuses on aggregated measures about the compliance of CGC recommendations to examine the effects of corporate governance on firms` financial distress.

CGC have several key universal principles for effective corporate governance (Aguilera and Cuervo- Cazurra, 2009) and have become widespread in the majority of developed economies. CGC are a form of soft regulations presenting a set of voluntary governance recommendations on relationships with shareholders and top management, the role and composition of the board of directors and its committees, auditing and information disclosure, and the selection, remuneration, and dismissal of directors and top managers (Duh, 2017). The main objective of CGC is to strengthen internal control and maximize shareholders' interests, which imply the safeguard of business prosperity. Despite the growing diffusion of CGC and the intense academic debate about the effectiveness of these codes, empirical evidence on the impact of CGC is still far from definitive. In particular, research on the effect of CGC compliance on firm outcomes is inconclusive and further exploration is required (Stiglbauer and Velte, 2014). Some studies suggest that the fulfillment with CGC recommendations leads to better strategic decisions and therefore document a positive association between CGC compliance and different measures of firm performance, such as price-to-book ratio, Tobin's q, or profitability (Fernández-Rodríguez et al., 2004; Stiglbauer, 2010; Luo and Salterio, 2014; Rodríguez-Fernández, 2016). Other authors have argued that CGC compliance can be used for ethical reasons to gain social legitimacy, which will improve investors' perceptions and lead to positive stock market reactions by improving firm value and share price development (Goncharov et al., 2006; Chavez and Silva, 2009; Kaspereit et al., 2015, 2017), and corporate reputation (Hooghiemstra and van Ees, 2011; McCahery et al., 2016). Nevertheless, many studies fail to support the previous associations (Bassen et al., 2009; McKnight and Weir, 2009; Jain et al., 2011; Stiglbauer and Velte, 2014; Steger and Stiglbauer, 2016).

Despite the increasing discussions on the determinants of financial distress and the significant debates on the effectiveness of CGC, the literature lacks analyzing whether CGC compliance may have an impact on firms' financial distress. The Spanish code, like most of the international CGC, includes a set of recommendations about general governance issues (such as anti-takeover mechanisms, functioning of the general meeting and mechanics of voting), as well as specific recommendations regarding the board of directors and its committees. Therefore, in this paper we aim to fill in the previous research gap by examining three different levels of CGC compliance: (1) the overall CGC compliance, (2) the compliance with the recommendations regarding boards of directors, and (3) the compliance with the recommendations related to board subcommittees. Since the main objective of corporate governance is to mitigate conflicts of interests between managers and shareholders (Shleifer and Vishny, 1997), the previous studies on CGC have largely relied on agency theory to explain the effects of their compliance (Cuomo et al., 2016). The separation of ownership and control in firms has been generally considered the origin of the agency problems (Jensen and Meckling, 1976; Fama and Jensen, 1983). According to agency theory, managers and majority shareholders have the opportunity to use corporate resources in ways that benefit themselves. Particularly, in environments with a high concentration ownership (like the Spanish context), large shareholders, who hold most of the voting rights, have a high power and may reach nearly full control over the governance of a firm, thus being detrimental for small investors (Shleifer and Vishny, 1986). In this scenario, large shareholders may exert an influence on management to maximize their own benefit regardless of the interests of minority shareholders (La Porta et al., 2000), who could suffer expropriation of their wealth, and this would increase the likelihood of financial distress in firms (Bona-Sánchez et al., 2018). Therefore, the struggle between the majority shareholders and the minority shareholders remains a basic agency problem (Renders and Gaeremynck, 2012). As a result, corporate governance mechanisms have been generally considered to be a solution to mitigate information asymmetries and agency conflicts in order to protect minority shareholders (Courteau et al., 2017). As a consequence, CGC recommendations must aim at protecting investors and reducing managerial opportunism (Zattoni and Cuomo, 2010), which is likely to guarantee companies' survival and therefore minimize the probability of business failure (Udin et al., 2017). In line with these premises, we explain the potential relationship between financial distress and the different measures of CGC compliance according to the arguments of agency theory.

First, the overall compliance with CGC recommendations should strengthen the corporate governance structures of a firm. Beyond the reinforcement of boards of directors and certain committees, those recommendations related with voting rights, annual meetings, and other general issues are also expected to safeguard shareholders` interests and improve governance mechanisms. Agency theory suggests that strong corporate governance prevents majority shareholders and managers from benefiting from a company at the cost of non-controlling shareholders and other stakeholders (Manzaneque et al., 2016a). This approach is the one most often used in the literature, which highlights that adequate monitoring or control mechanisms of managerial decision-making processes are required in order to protect shareholders and other investors (Kiel and Nicholson, 2003; Stiglbauer and Velte, 2014). As a result, weak corporate governance may increase the probability of opportunistic behavior of management or majority shareholders, which could lead to an ethical conflict with shareholders and prioritize their personal aims against the overall company objective (La Porta et al., 2000). Therefore, a high degree of overall CGC compliance may decrease the wealth expropriation risk and, in turn, minimize the probability of a company failure (Lee and Yeh, 2004). Additionally, a reduction in agency conflicts would lead to important benefits for firms that are likely to improve its financial situation, such as more access to capital, reduction in cost of capital (Reddy et al., 2010), secure access to financial assets (Weber and Velte, 2011), and also would attract investment opportunities and improve capital market developments (Udin et al., 2017). According to the previous arguments, if the compliance of the overall recommendations included in the CGC reduces agency costs and reinforces the quality of corporate governance structures, a higher degree of compliance should reduce the likelihood of financial distress of a firm. Hence, the following hypothesis is formulated: 
H1. The overall compliance of CGC will reduce the likelihood of financial distress.

On the other hand, boards of directors are a crucial corporate governance mechanism (Adams et al., 2010), since they are the highest level authority in the decision-making within a firm and exert considerable power over corporate strategic actions (Galbreath, 2018). The board of directors is an essential control system which develops decisive internal monitoring activities such as the evaluation of tasks carried out by the top management and the CEO, and the evaluation of firm strategy (Pugliese et al., 2009), which is expected to minimize the costs incurred when management pursues its own interests at the expense of the shareholders' interests (Hillman and Dalziel, 2003). Specifically, boards must be responsible to monitor decisions to detect and avoid financial instability (Chang, 2009; Manzaneque et al., 2016a), and to impose the necessary measures to help overcome a possible failure situation (Fich and Slezak, 2008). For that reason, the vast majority of CGC explicitly include a set of recommendations on the board of directors (Aguilera and Cuervo- Cazurra, 2009). These recommendations aim to strengthen the degree of independence, the qualification, the diversity and the pool resources of directors, the functioning of the board, among other characteristics. These features are expected to provide the board with valuable skills and competence, which results in a better ability to monitor the discipline of managers and majority shareholders, and enhances board effectiveness in the oversight of corporate strategies (Huse and Solberg, 2006; Srinidhi et al., 2011). Therefore, a higher compliance with these recommendations must lead boards to be in a better position to monitor business decisions to minimize the risk of failure (Dowell et al., 2011) and assure the financial situation of the firm (Simpson and Gleason, 1999). In line with the previous arguments, we assume that boards with a higher compliance of CGC recommendations are in a better position to reduce the probability of financial distress, and therefore the following hypothesis is formulated:

H2. The compliance of CGC recommendations regarding the board of directors will reduce the likelihood of financial distress.

Corporate governance mechanisms also include several board subcommittees, such as the audit committee, the nomination committee, the compensation committee, or the corporate governance committee. These committees are responsible for strategic planning and play an important role in the oversight of corporate strategies to protect the interests of the shareholders (Detthamrong et al., 2017; Orazalin, 2019). The compliance of the recommendations related to these committees should improve the quality of the governance of a firm and therefore the effectiveness of corporate governance structures in the development of their monitoring functions, thus mitigating agency costs and information asymmetries. In particular, these committees may serve as an additional mechanism to control the opportunistic behavior of managers and minimize the influence of majority shareholders (Hamid et al., 2016). First, the audit committee has attracted great interest since it has become a key element to control and monitor management (Ruzaidah and Takiah, 2004). This committee is expected to oversee the strategic actions of a firm and specifically any financial or operational issues (Rahmat et al., 2009). The previous literature agrees that audit committees are needed to resolve agency conflicts and to maintain good performance (Klein, 2002). Therefore, the audit committee is responsible for decisions that should assure business prosperity and mitigate the financial distress of companies (Salloum et al., 2014). On the other hand, although most of the attention paid by academics and professionals focuses on the audit committee, the other committees are also important to reduce agency conflicts, which can result in improvements in a firm's financial situation. For instance, the nomination committee can impact on the monitoring process of the strategic actions, since this committee is likely to minimize the influence of leaders on the selection process (Shivdasani and Yermack, 1999; Baklouti et al., 2016). In addition, the compensation committee is in charge of the evaluation of the performance of management and the creation of appropriate compensation packages and hence this committee may limit agency problems by introducing incentives structures designed to align the objectives of senior management with those of shareholders (Uzun et al., 2004). Finally, the corporate governance committee focuses more specifically on the standards of qualification of the directors, and their responsibilities, and it enhances the responsibility of directors in decision making and leads to a better monitoring (Mahoney and Shuman, 2003). Therefore, the configuration of these committees remains relevant to guarantee the quality of governance structures. In theory, the compliance of CGC recommendations regarding the board subcommittees should enhance the effectiveness of these committees and improve their monitoring functions, which may lead to reducing the likelihood of financial distress. Therefore, the following hypothesis is formulated:

H3. The compliance of CGC recommendations regarding the board subcommittees will reduce the likelihood of financial distress.

\section{Research method}

\subsection{Sample and data}

Our empirical analysis considers the 36 firms that were listed on the IBEX-35 for the period 2013-2016, and our sample is composed of 130 observations. The sample size has been proven to have sufficient statistical power in many recent studies using similar analyses (Akkermans et al., 2007; Ahmadi et al., 2018; Neifar and Jarboiu, 2018). In line with previous research, the largest firms are selected because of their representativeness (Goncharov et al., 2006; Albu and Girbina, 2015) and since they present greater agency costs and therefore corporate governance mechanisms are expected to be crucial (Karamanou and Vafeas, 2005). Particularly, agency conflicts are likely to be especially significant in Spanish firms, due to their special characteristics in relation to corporate governance, such as concentrated ownership and control, and a system based on a unitary board structure strongly dominated by the controlling shareholders (Acero and Alcalde, 2013; Manzaneque et al., 2016a). These characteristics make the Spanish context an interesting scenario to understand the role of corporate governance structures in the safeguard of the interests of all shareholders and stakeholders (La Porta et al., 1999; Manzaneque et al., 2016b).

The data needed to calculate the variables about CGC compliance were extracted from the Spencer Stuart Index report, which provides 
information about the compliance of every recommendation in the Spanish CGC. On the other hand, the financial data used to compute variables about financial distress and other control variables were obtained from the SABI database and companies' annual accounts.

\subsection{Variables}

\subsubsection{Dependent variable: financial distress}

Consistent with the approach used by recent studies (Pindado et al., 2008; Manzaneque et al., 2016b; Mangena et al., 2020), the measurement for financial distress (FD) was calculated as a binary variable that takes the value 1 if the company meets the following conditions and 0 if not: (1) its earnings before interest and taxes depreciation and amortization (EBITDA) are lower than its financial expenses for two consecutive years; (2) a fall in its market value occurs between two consecutive periods ${ }^{1}$. This ex-ante approach is especially advantageous since it allows overcoming problems of the ex-post business failure approaches by considering crisis situations other than bankruptcy (Grice and Dugan, 2001).

In order to increase the robustness of our empirical study and ensure that our results are not influenced by the use of a specific measure, a sensitivity analysis is performed by alternatively employing a continuous variable based on the Zmijewski score (Zmscore). The Zmijewski model (Zmijewski, 1984) has been extensively used in recent studies on business failure (Tykvová and Borell, 2012; Richardson et al., 2015b; Lee et al., 2017) due to its high capacity to predict financial distress in comparison with older models (Husein and Pambekti, 2015). This score is calculated as follows:

$\mathrm{Zm}=-4.336-4.513 * \mathrm{X} 1+5.679 * \mathrm{X} 2-0.004 * \mathrm{X} 3$

where $\mathrm{x} 1=$ net income/total assets, $\mathrm{x} 2=$ total debt/total assets, and x $3=$ current assets/current liabilities. Firms with a value over 0.5 are classified as distressed companies.

\subsubsection{Explanatory variables}

Our main explanatory variables are related to the compliance of CGC recommendations. Consistent with previous research (Campbell et al., 2009; Rodríguez-Fernández, 2016), these variables were calculated as the proportion of recommendations fulfilled by firms. In the calculation of CGG measures, we eliminated the non-applicable recommendations for each company. Specifically, in our paper, three variables were considered: (1) the overall CGC compliance, measured by the proportion of total recommendations satisfied by a firm (Overall); (2) the compliance with the recommendations about board of directors, calculated as the proportion of recommendations related with the boards of directors fulfilled by a firm (Board); (3) the compliance with the recommendations about board subcommittees, measured by the proportion of recommendations strictly related with these subcommittees fulfilled by a firm (Subcommittees). The overall CGC compliance deals with a number of very different issues (64 items) in addition to the recommendations on the board of directors and its committees, such as anti-takeover mechanisms, responsibilities of the general meeting and mechanics of voting. The recommendations about the board of directors ( 25 items) also include a variety of topics, related to the size and composition of the board, the characteristics of directors, the activity and meetings, among others. Finally, the recommendations about the board subcommittees (28 items) include issues strictly related to the structure and functioning of the audit committee, the nomination committee, the compensation committee, and the corporate governance committee. All these recommendations are strictly voluntary and can be seen in Annex 1 .

\subsubsection{Control variables}

In line with the previous literature, several variables which can influence the financial distress of firms were also considered (Parker et al., 2002; Wang and Deng, 2006; Shahwan, 2015; Udin et al., 2017): firm size, leverage, financial performance, profit margin, industry and year. The literature generally argues that the likelihood of financial distress is positively associated with firm leverage and inversely related to firm size, financial performance and profit margin. Additionally, as the financial situation of a firm may differ across industries and across time periods, both variables are also included. Firm size (Size) is measured as the logarithm of total assets. Leverage (Lev) is calculated as the ratio of total debt to total assets. Financial performance (Fperf) is proxied by the ratio return on equity. Profit margin (Pmargin) is computed as the net income over net sales. In order to consider the industry (Ind) in which the firm operates, dichotomous variables are created based on the classification of sectors provided by the General Index of the Madrid Stock Exchange. Finally, dummy variables are also calculated to include the years (Year) in the statistical model. Table 1 provides a summary of all the variables and their definitions and Table 2 summarizes the frequency and percentage of each industrial sector in the population.

\subsubsection{Model specification}

Recent research claims that the reasons that might explain the lack of conclusive findings on the association between the compliance with CGC and firm outcomes can be related to methodological issues, including the use of ordinary least squares (OLS) regression and the insufficient attention to endogeneity concerns (Cuomo et al., 2016). In this paper, we attempt to address these limitations by using both a conditional logistic regression analysis and specific tests to control for endogeneity issues.

As commented above, two variables were included in the empirical analysis as a proxy for financial distress. On the one hand, since the first measure (FD) is a dichotomous variable, a logistic regression model is applied to estimate the financial distress likelihood. The

${ }^{1}$ Other previous studies on business failure have also employed this proxy, a major revision can be found in Manzaneque (2006). 
Table 1

Definition of variables.

\begin{tabular}{|c|c|c|}
\hline Variables & Description & Source \\
\hline FD & $\begin{array}{l}\text { Dummy which takes the value } 1 \text { if: (1) its EBITDA are lower than its financial expenses for two consecutive years; (2) a } \\
\text { fall in its market value occurs between two consecutive periods }\end{array}$ & Annual accounts \\
\hline Zmscore & Zmijewski score & Annual accounts \\
\hline Overall & The proportion of recommendations contained in CGC fulfilled by firms & $\begin{array}{l}\text { Spencer Stuart } \\
\text { Index }\end{array}$ \\
\hline Board & The proportion of recommendations about the board of directors contained in CGC fulfilled by firms & $\begin{array}{l}\text { Spence Stuart } \\
\text { Index }\end{array}$ \\
\hline Subcommittees & The proportion of recommendations about the board subcommittees contained in CGC fulfilled by firms & $\begin{array}{l}\text { Spencer Stuart } \\
\text { Index }\end{array}$ \\
\hline Size & Logarithm of total assets & Annual accounts \\
\hline Lev & Ratio of total debt to total assets & Annual accounts \\
\hline Fperf & Ratio return on equity & Annual accounts \\
\hline Pmargin & Net income over net sales & Annual accounts \\
\hline Ind & Industry & $\begin{array}{l}\text { Madrid Stock } \\
\text { Exchange }\end{array}$ \\
\hline Year & Year & \\
\hline
\end{tabular}

Table 2

Composition of the population and sample firms according to the industry type.

\begin{tabular}{lll}
\hline Industry & N & \% \\
\hline Basic Materials and Industry & 37 & 17 \\
Consumer Services & 11 & 13 \\
Consumer Goods & 31 & 9 \\
Technology and Telecommunications & 22 & 9 \\
Financial and Real Estate Services & 130 & 17 \\
Oil and Energy & 100 \\
Total & & 31 \\
\hline
\end{tabular}

consideration of this variable has important advantages in the measurement of financial distress and, at the same time, the use of this methodology overcomes the handicaps of OLS to estimate the parameters when the dependent variable is dichotomous (Mangena and Chamisa, 2008), and is consistent with recent research on the determinants of the financial distress of firms (Shahwan, 2015; Manzaneque et al., 2016b; Udin et al., 2017). The models used in this logistic analysis are represented as follows:

Model 1: $F D_{i t}=\alpha+\beta_{1}$ Overall $_{i t}+\beta_{2}$ Size $_{I t}+\beta_{3}$ Lev $_{i t}+\beta_{4}$ Fperf $_{i t}+\beta_{5}$ Pmargin $_{\mathrm{it}}+\beta_{6}$ Ind $_{i t}+\beta_{7}$ Year $_{i t}$

Model 2: $F D_{i t}=\alpha+\beta_{1}$ Board $_{i t}+\beta_{2}$ Size $_{I t}+\beta_{3}$ Lev $_{i t}+\beta_{4}$ Fperf $_{i t}+\beta_{5}$ Pmargin $_{\mathrm{it}}+\beta_{6}$ Ind $_{\text {it-1 }}+\beta_{7}$ Year $_{\text {it }}$

Model 3: $F D_{i t}=\alpha+\beta_{1}$ Subcommittees $_{i t}+\beta_{2}$ Size $_{I t}+\beta_{3}$ Lev $_{i t}+\beta_{4}$ Fperf $_{i t}+\beta_{5}$ Pmargin $_{\mathrm{it}}+\beta_{6}$ Ind $_{i t}+\beta_{7}$ Year $_{\text {it }}$

Where $i$ and $t$ denote the cross-sectional units and time period, respectively.

On the other hand, one possible problem when analyzing linkages between corporate governance and firm outcomes is the issue of endogeneity between the dependent and independent variables (Adams and Ferreira, 2009). We control the endogeneity issue using a two-stage least squares method (2SLS). This methodology requires the use of instrumental variables that should be highly related to the endogenous independent variable and unrelated to the dependent variable (Larcker and Rusticus, 2010). These instruments must be relevant and exogenous. Relevant instruments are significantly correlated with the endogenous variable conditional on the other variables (relevance condition). Exogenous instruments require that they are determined outside of the model and not correlated with the error (exclusion condition). In our empirical analysis, we use as instrumental variables: (1) corporate reputation and (2) corporate social responsibility. Corporate reputation and corporate social responsibility practices are expected to be correlated with the CGC compliance since the relationship between corporate governance structures and both corporate reputation and corporate social responsibility is well documented in the literature (Fombrun et al., 2015; Li et al., 2017; Javed et al., 2020). In addition, the validity of these instruments is confirmed taking into consideration the values obtained from the Sargan test, which are reported in the next section. Consistent with previous research (Delgado-García et al., 2010; Odriozola and Baraibar-Diez, 2017), the first instrument is calculated as a dummy variable, which takes the value of 1 if a company appears in the ranking of the most reputable firms provided by $\mathrm{MERCO}^{2}$, and 0 otherwise; and the second instrument as a dummy variable which takes the value of 1 if a company appears in the ranking of the most socially responsible firms provided by MERCO, and 0 otherwise. It is worth mentioning that, in this endogeneity analysis, we used a continuous dependent variable and therefore consider our second measure of financial distress, the Zmijewski score

\footnotetext{
${ }^{2}$ MERCO (Monitor Español de Reputación Corporativa) annually publishes a ranking of the most reputable firms in Spain. This ranking, similar to the ones released in other contexts, such as the one provided by Fortune in the United States, has become a reference in Spain in the assessment of corporate reputation (Sánchez and Sotorrío, 2007).
} 
(Zmscore). The models used in this empirical analysis are as follows:

Model 1: Zmscore $_{i t}=\alpha+\beta_{1}$ Overall $_{i t}+\beta_{2}$ Size $_{I t}+\beta_{3}$ Lev $_{i t}+\beta_{4}$ Fperf $_{i t}+\beta_{5}$ Pmargin $_{\mathrm{it}}+\beta_{6}$ Ind $_{i t}+\beta_{7}$ Year $_{i t}$
Model 2: Zmscore $_{i t}=\alpha+\beta_{1}$ Board $_{\text {dit }}+\beta_{2}$ Size $_{I t}+\beta_{3}$ Lev $_{i t}+\beta_{4}$ Fperf $_{i t}+\beta_{5}$ Pmargin $_{\mathrm{it}}+\beta_{6}$ Ind $_{i t}+\beta_{7}$ Year $_{i t}$
Model 3: Zmscore $_{i t}=\alpha+\beta_{1}$ Subcommittees $_{i t}+\beta_{2}$ Size $_{I t}+\beta_{3}$ Lev $_{i t}+\beta_{4}$ Fperf $_{i t}+\beta_{5}$ Pmargin $_{\mathrm{it}}+\beta_{6}$ Ind $_{i t}+\beta_{7}$ Year $_{i t}$

\section{Results and discussion}

\subsection{Descriptive statistics and correlations}

Table 3 displays the descriptive statistics for the variables included in our statistical analyses. The mean value for our first variable of financial distress (FD) is 0.492 , thus indicating that almost half of the companies in our sample presented financial problems. This high value can be expected since this measure is based on a broad definition of business failure, including not only bankruptcy, but identifying firms that may have problems in meeting financial obligations (Manzaneque et al., 2016b). This value is particularly conditioned by the downturn in the earnings and market values of many firms listed in the IBEX35 in the period analyzed ${ }^{3}$. However, the values from the Zmijewski score (Zmscore) indicate that the likelihood of business failure is lower. In line with recent studies (Husein and Pambekti, 2015; Cano-Rodríguez et al., 2016), most of the firms of our sample present a low likelihood of financial distress according to the Zmijewski score, which is a more restrictive measure of financial distress, designed to specifically predict bankruptcy. In relation to the CGC compliance, it can be observed that, although the recommendations included in the Spanish CGC are strictly voluntary, the degree of fulfillment is high ${ }^{4}$, regardless of the type of recommendation. This result is consistent with the findings reported by recent studies in the European context (Kabbach de Castro et al., 2017). Table 3 shows that while some firms comply with about half of the recommendations, most of them have a high level of compliance. Despite the flexibility in the application of the Spanish CGC, this serves as a benchmark for good corporate governance practices, and the largest firms may have a higher responsibility or pressure to fulfill all the recommendations in order to mitigate reputation costs.

The sample correlations between all the variables are reported in Table 4. First, our two measures for financial distress are significantly correlated. Despite this association, bivariate correlations between the measures of financial distress variables and CGC compliance measures provide mixed results. Furthermore, there is a strong association between the three variables on CGC compliance. The firms that present a higher overall CGC compliance also tend to highly fulfill the specific recommendations regarding the board of directors and its subcommittees. In addition, consistent with the theoretical arguments, several control variables appear to be correlated with both measures for financial distress. Finally, the correlation coefficients between independent variables are not high. A rule of thumb is that multicollinearity may be a problem if a correlation is 0.7 or more in the correlation matrix formed by the independent variables (Cooper and Schindler, 2003). Therefore, multicollinearity issues in our sample are discarded.

\subsection{Multivariate analysis}

On the one hand, the results from the logistic regression analysis panel are reported in Table 5. In Model 1, we test the relationship between the overall CGC compliance (Overall) and the likelihood of financial distress (FD). In Models 2 and 3, the main explanatory variables refer to the compliance of recommendations regarding the board of directors (Board) and its subcommittees (Subcommittees), respectively. All the models are statistically significant and include the control variables commented. The results fail to find any significant relationship between the likelihood of financial distress and either the overall CGC compliance or CGC compliance about subcommittee recommendations. Nonetheless, the compliance of CGC recommendations on boards of directors is significantly related to the probability of financial distress. As predicted in our hypothesis H2, boards that comply with CGC recommendations seem to be in a better position to carry out their monitoring function effectively and therefore to better prevent business failures. With reference to the control variables, in line with previous studies (Shahwan, 2015; Udin et al., 2017) the likelihood of financial distress is documented to increase for greater levels of leverage and to decrease for higher levels of firm performance in all the models. As expected, a larger leverage could enhance the likelihood of financial distress because of an enhancement in financial costs and the risks from the repayment of debts. In addition, lower firm performance might be associated to higher levels of market risk and fewer resources to face financial obligations, thus increasing the likelihood of financial distress.

On the other hand, in the next stage of the empirical analysis, Table 6 reports the results from the two-stage procedure (2SLS), where the analysis is performed by using the instrumental variables to predict the level of CGC compliance. The instruments comply with the theoretical requirements and Sargan's test also confirms their validity. The literature assumes that p-values over 0.10 signal

\footnotetext{
${ }^{3}$ In the period analyzed, Spanish firms listed in the IBEX35 were significantly affected by the crisis related to emerging economies, interest rates policies, and political instability.

${ }^{4}$ In Spain, the terms considered basic and indispensable with respect to companies' corporate governance have been written into legislation, while the recommendations contained in the CGC remain strictly voluntary, under the internationally recognized "comply or explain" approach, which is used in main European Union states and other developed countries.
} 
Table 3

Descriptive statistics.

\begin{tabular}{|c|c|c|c|c|c|c|c|}
\hline Variables & Mean & Min. & Max. & St. dev. & Q1 & Median & Q3 \\
\hline FD & 0.492 & 0 & 1 & 0.502 & 0 & 0 & 1 \\
\hline Zmscore & -17.14 & -283.483 & 509.897 & 71.354 & -37.667 & -15.883 & -0.374 \\
\hline Overall & 91.181 & 50.250 & 100 & 9.090 & 88.002 & 93.54 & 98.24 \\
\hline Board & 90.752 & 61.900 & 100 & 9.066 & 84 & 94.44 & 100 \\
\hline Subcommittees & 90.916 & 53.570 & 100 & 9.309 & 85.58 & 94.12 & 100 \\
\hline Size & 7.047 & 5.673 & 8.696 & 0.807 & 6.493 & 6.845 & 7.574 \\
\hline Lev & 0.632 & 0.050 & 2 & 0.305 & 0.378 & 0.695 & 0.89 \\
\hline Fperf & 6.359 & -489.590 & 110.970 & 58.434 & 2.685 & 7.6 & 19.067 \\
\hline Pmargin & 0.211 & -24.470 & 13.460 & 3.117 & 0.06 & 0.21 & 0.675 \\
\hline
\end{tabular}

See Table 1 for the definition of the dependent, explanatory and control variables.

Table 4

Pearson coefficients.

\begin{tabular}{lllllll}
\hline & $(1)$ & $(2)$ & $(3)$ & $(4)$ & $(5)$ & $(6)$ \\
\hline (1) FD & 1 & & & & \\
(2) Zmscore & $0.245^{* * *}$ & 1 & & & \\
(3) Overall & -0.094 & $-0.288^{* * *}$ & 1 & & \\
(4) Board & -0.142 & $-0.167^{*}$ & $0.640^{* * *}$ & 1 & & \\
(5) Subcommittees & -0.038 & $-0.215^{* *}$ & $0.773^{* * *}$ & $0.509^{* * *}$ & 1 & 0.127 \\
(6) Size & -0.039 & $0.207^{* *}$ & $0.148^{*}$ & 0.106 & 1 \\
(7) Lev & $0.222^{* *}$ & $0.557^{* * *}$ & -0.104 & -0.069 & -0.054 & $0.414^{* * *}$ \\
(8) Fperf & $-0.222^{* *}$ & $-0.469^{* * *}$ & -0.042 & 0.032 & -0.013 & -0.057 \\
(9) Pmargin & $-0.157^{*}$ & $-0.465^{* * *}$ & 0.064 & -0.022 & 0.019 & -0.020 \\
\hline
\end{tabular}

See Table 1 for the definition of the dependent, explanatory and control variables. ${ }^{*}$ p-value $<0.1 ; * *$-value $<0.05 ; * * * \mathrm{p}$-value $<0.01$.

Table 5

Logistic regression analysis.

\begin{tabular}{lll}
\hline Dependent variable: FD & & \\
\hline & Model 1 & Model 2 \\
\hline Overall & $-0.0045(-0.16)$ & $-0.0464^{*}(-1.80)$ \\
Board & & \\
Subcommittees & & $-0.6986(-1.48)$ \\
Size & $-0.6210(-1.32)$ & $2.9640^{* * *(2.82)}$ \\
Lev & $2.9248^{* * *}(2.83)$ & $-0.0262^{* * *(-2.57)}$ \\
Fperf & $-0.0251^{* *}(-2.46)$ & $-0.0626(-0.71)$ \\
Pmargin & $-0.0347(-0.43)$ & $-0.6203(-1.32)$ \\
Ind & included & included \\
Year & included & included \\
Wald & $22.36^{*}$ & $24.14 * 0.0250^{* *}(-2.47)$ \\
\hline
\end{tabular}

See Table 1 for the definition of the dependent, explanatory and control variables. In this table, we report results from logit regression analysis of the mode: $\mathrm{FD}_{\mathrm{it}}=\alpha+\beta_{1}$ Overall $_{\text {it }}+\beta_{2}$ Board $_{\text {it }}+\beta_{3}$ Subcommittees $_{\text {it }}+\beta_{4}$ Size $_{\text {it }}+\beta_{5}$ Lev $_{\text {it }}+\beta_{6}$ Fperf $_{\text {it }}+\beta_{7}$ Pmargin $_{\text {it }}+\beta_{8}$ Ind $_{\text {it- } 1}+\beta_{9}$ Year $_{\text {it- } 1 .}{ }^{*}$ p-value $<$ $0.1 ; * *$ p-value $<0.05 ; * * *$ p-value $<0.01$. Wald refers to a statistical significance test for the model in logistic regressions.

that the instruments are uncorrelated with the error term (García-Castro et al., 2010). Results of the F-test show that the regression models are all statistically significant at the levels of 0.001 and 0.05 . This analysis confirms that the likelihood of financial distress, measured by the Zmijewski score, is also significantly associated with the compliance with CGC recommendations about the board of directors. In particular, the adjusted R2 for Model 2 is 0.250 , suggesting that it explains an important variance in the dependent variable. Furthermore, the results again show the lack of association between financial distress and both the level of overall CGC compliance and the compliance of the recommendations regarding board subcommittees. In addition to the leverage and firm performance, the profit margin appears to be significantly associated with the financial distress of firms.

Our evidence specifically extends the literature on corporate governance and business failure. First, in the last years, the proliferation of CGC has led to increasing research on the effects of their compliance. While many studies have focused on the impact that CGC compliance could have on investors' perceptions (Hooghiemstra and van Ees, 2011; McCahery et al., 2016; Kaspereit et al., 2017), some recent studies suggest that the fulfillment of CGC recommendations may also have economic and financial effects and call for further research on this issue (Stiglbauer and Velte, 2014; Haji and Mubaraq, 2015; Cuomo et al., 2016; Rose, 2016). Our paper complements these studies and helps to explain the previous mixed evidence, thereby providing an important contribution to the existing literature.

On the one hand, we highlight that CGC compliance is not only an ethical issue, as it may also help to prevent financial distress, 
Table 6

2SLS analysis.

\begin{tabular}{llll}
\hline Dependent variable: Zmscore & & & Model 2 \\
\hline & Model 1 & & Model 3 \\
\hline Global & $-22.7270(-1.09)$ & $-16.3657^{*}(-1.73)$ & $-17.2914(-1.53)$ \\
Board & & & $5.5860(0.05)$ \\
Subcommittees & $109.2534(0.56)$ & $25.0973(0.25)$ & $123.2447(0.69)$ \\
Size & $-41.1853(-0.11)$ & $281.2328^{* * *}(3.16)$ & $-0.5552^{* * *}(-3.23)$ \\
Lev & $-0.3836^{*}(-1.67)$ & $-0.3436^{* *}(-2.27)$ & $-3.0764(-1.00)$ \\
Fperf & $-8.0933(-1.17)$ & $-6.8510^{*}(-1.80)$ & included \\
Pmargin & included & included & included \\
Ind & included & included & 0.764 \\
Year & 0.853 & 0.830 & 0.061 \\
Sargan test & 0.217 & 0.250 & $4.76^{* * *}$ \\
Adjusted R2 & $2.42^{* *}$ & $6.15^{* *}$ & \\
F test & & & \\
\hline
\end{tabular}

See Table 1 for the definition of the dependent, explanatory and control variables. In this table, we report results from logit regression analysis of the mode: Zmscore $_{i t}=\alpha+\beta_{1}$ Overall $_{\text {it }}+\beta_{2}$ Board $_{\text {it }}+\beta_{3}$ Subcommittees $_{\text {it }}+\beta_{4}$ Size $_{\text {it }}+\beta_{5}$ Lev $_{\text {it }}+\beta_{6}$ Fperf $_{\text {it }}+\beta_{7}$ Pmargin $_{\text {it }}+\beta_{8}$ Ind $_{\text {it-1 }}+\beta_{9}$ Year $_{\text {it-1. }}{ }^{*}$ p-value $<0.1 ; * *$ p-value $<0.05 ; * *$ p-value $<0.01$.

which is a crucial firm outcome (Boubaker et al., 2018). On the other hand, we show that the analysis of CGC compliance must take into consideration the differences between the recommendations contained in CGC. Specifically, one of the novelties of our study is the design of three measures for CGC compliance based on types of recommendations common to all the existing CGC across the world.

In particular, an overall CGC compliance lacks adding value in terms of mitigating the financial distress of companies. This finding leads us to support that not all corporate governance recommendations might have an impact on firm strategies, which may help to explain the lack of association between CGC and firm outcomes documented in several previous studies (Bassen et al., 2009; Jain et al., 2011; Steger and Stiglbauer, 2016). As the relationship between the overall CGC compliance and financial distress appears to be insignificant, our hypothesis $\mathrm{H} 1$ cannot be accepted. The measure for overall CGC compliance includes recommendations of a different nature and not all of them might be effective to minimize agency costs, which can explain that a global effect is lacking. Furthermore, we fail to find a relationship between the compliance of CGC recommendations about board subcommittees and financial distress, thus rejecting our hypothesis H3. Since these recommendations jointly consider aspects of different committees, it might be possible for the results to be influenced by the fact that the monitoring ability differs from one committee to another. Only the compliance with the CGC recommendations regarding the board of directors leads to a reduction in the likelihood of financial distress and, as a result, our hypothesis $\mathrm{H} 2$ can be accepted. In line with the previous research, our findings suggest the board of directors is in charge of the monitoring of major strategic decisions to detect business failure (Fich and Slezak, 2008; Manzaneque et al., 2016a). These results help to enhance the understanding about the effects of boards, especially in environments with a high ownership concentration, as the board-related recommendations may serve to reduce agency conflicts from opportunistic behaviors of managers and majority shareholders, and minimize the likelihood of financial distress. Therefore, the role of the board of directors in firms with majority shareholders may be essential to align the interests of the minority and large shareholders, thus leading to making decisions that could positively influence the likelihood of financial distress. This is an important contribution for the literature on boards of directors, since the traditionally commented role of boards in the mitigation of agency conflicts (Hillman and Dalziel, 2003) is reinforced. Our results indicate that, in addition to the basic and mandatory board of director terms, the ability of boards to reduce agency problems can be enhanced by their compliance with voluntary recommendations included in CGC (i.e., board size, director selection and resignation policies, director attendance, the frequency of board meetings, training programs, the functions of directors, and board information on specific issues).

Furthermore, we also extend the previous literature on the determinants of financial distress. A few studies document that governance structures, such as the level of independence or the ownership structure can influence the likelihood of financial distress (Salloum et al., 2013; Baklouti et al., 2016; Manzaneque et al., 2016b; Udin et al., 2017). We extend this branch of literature by shedding some light on the impact of CGC compliance.

\section{Conclusions}

This paper provides new empirical evidence concerning the effect of CGC compliance on the likelihood of financial distress of firms. The relationship between corporate governance and financial distress is a matter of interest to different stakeholders, and yet there is no empirical evidence regarding the impact of CGC on this issue.

Unlike previous studies, we examine three different levels of CGC compliance: the overall CGC compliance, the compliance with the recommendations about the board of directors, and the compliance with the recommendations about the board subcommittees. We find that the probability of financial distress may be reduced for higher levels of compliance with the recommendations regarding the board of directors. However, the other measures of CGC compliance appear unrelated with the proxies employed for financial distress.

These findings have both practical and academic implications. Corporate governance reforms have increasingly been promoted worldwide to strengthen the performance of capital markets through a reduction in agency costs and a protection of shareholders' 
rights (Udin et al., 2017). In this regard, the introduction and implementation of CGC have become essential for policymakers and practitioners around the world. Indeed, in the last years the good management of companies has become a key objective in capital markets, and all the developed countries have introduced or revised their national CGC.

The common approach of these codes is consistent with the idea that CGC recommendations must improve firm outcomes. However, there are ongoing debates about the actual effect of compliance with CGC recommendations. Therefore, more empirical research on this issue is required in order to ascertain whether CGC compliance is merely an ethical or reputational issue, or has a direct impact on the financial situation of firms. Given the relevance of financial distress as a firm financial outcome, our evidence presents a strong business case concerning compliance with CGC and contributes to the debates about the impact of these codes. In this sense, firms can benefit from our evidence and better understand the effects of CGC compliance. In particular, companies may be aware of the need to set up specific corporate governance mechanisms, especially related to the board of directors, which are likely to improve the ability to monitor and reduce the likelihood of financial distress. In addition, the results can be useful for policymakers in the configuration of requirements and recommendations regarding corporate governance structures. Since certain recommendations appear to be more effective in the mitigation of agency problems and the minimization of financial distress, regulators may also use our evidence to consider the incorporation of these voluntary recommendations into mandatory laws. Particularly, our study focuses on the Spanish context, where the special characteristics of corporate governance, such as high ownership concentration, are likely to raise serious agency conflicts. Therefore, our findings may be particularly relevant for policymakers and firms in most continental European states, and Asian countries like Japan, where the conflict between majority shareholders and minority shareholders is also common.

From an academic view, our findings provide guidance for future studies on CGC compliance and emphasize the need to distinguish between the different types of recommendations to investigate the effects of CGC. Specifically, our three measures for CGC compliance are applicable to all countries and therefore provide encouraging research opportunities to further explore the impact of CGC. Our study also has academic implications through a better understanding of agency theory, by indicating that compliance with certain CGC recommendations may mitigate agency conflicts. In addition, our evidence may help to refine models for the prediction of financial distress, which could include not only economic and financial data, but also variables related to corporate governance.

This study presents certain limitations and interesting avenues for future research. First, although Spain offers a very relevant scenario for the analysis of the association between corporate governance and financial distress, and the results may be generalizable to similar contexts, future studies could investigate different legal and/or institutional contexts. For instance, upcoming research might analyze the effects of CGC compliance in contexts with a low ownership concentration. Second, we also provide new measures about the level of CGC compliance, which may be extended to be taken into consideration for further exploration about the effects of CGC on other firm outcomes. In addition, researchers can explore the impact on financial distress of specific board subcommittees or even specific recommendations.

\section{CRediT authorship contribution statement}

Francisco Bravo-Urquiza: Conceptualization, Formal analysis, Investigation, Methodology, Supervision, Writing - original draft, Writing - review \& editing. Elena Moreno-Ureba: Data curation, Investigation, Methodology, Software, Visualization.

\section{Declaration of Competing Interest}

The authors report no declarations of interest.

\section{Acknowledgments}

This work was supported by the Spanish Ministry of Economy and Competitiveness [Projects ECO2015-69637-R].

\section{Appendix A. List of CGC recommendations}

\begin{tabular}{ll}
\hline Overall recommendations (64) \\
\hline No voting limitation \\
Information related to the parent and subsidiary company \\
Information to General Meeting of Shareholders on compliance with corporate governance \\
Communications with shareholders and investors \\
Limit issue of shares without preferential subscription rights \\
Mandatory reports on webs \\
General Meeting of Shareholders webcast \\
Annual Accounts presentation by audit committee without qualifications \\
Web publication attendance and voting requirements \\
Possibility of including topics on the agenda at the proposal of the shareholders \\
Attendance premium policies \\
Performance of functions on boards
\end{tabular}




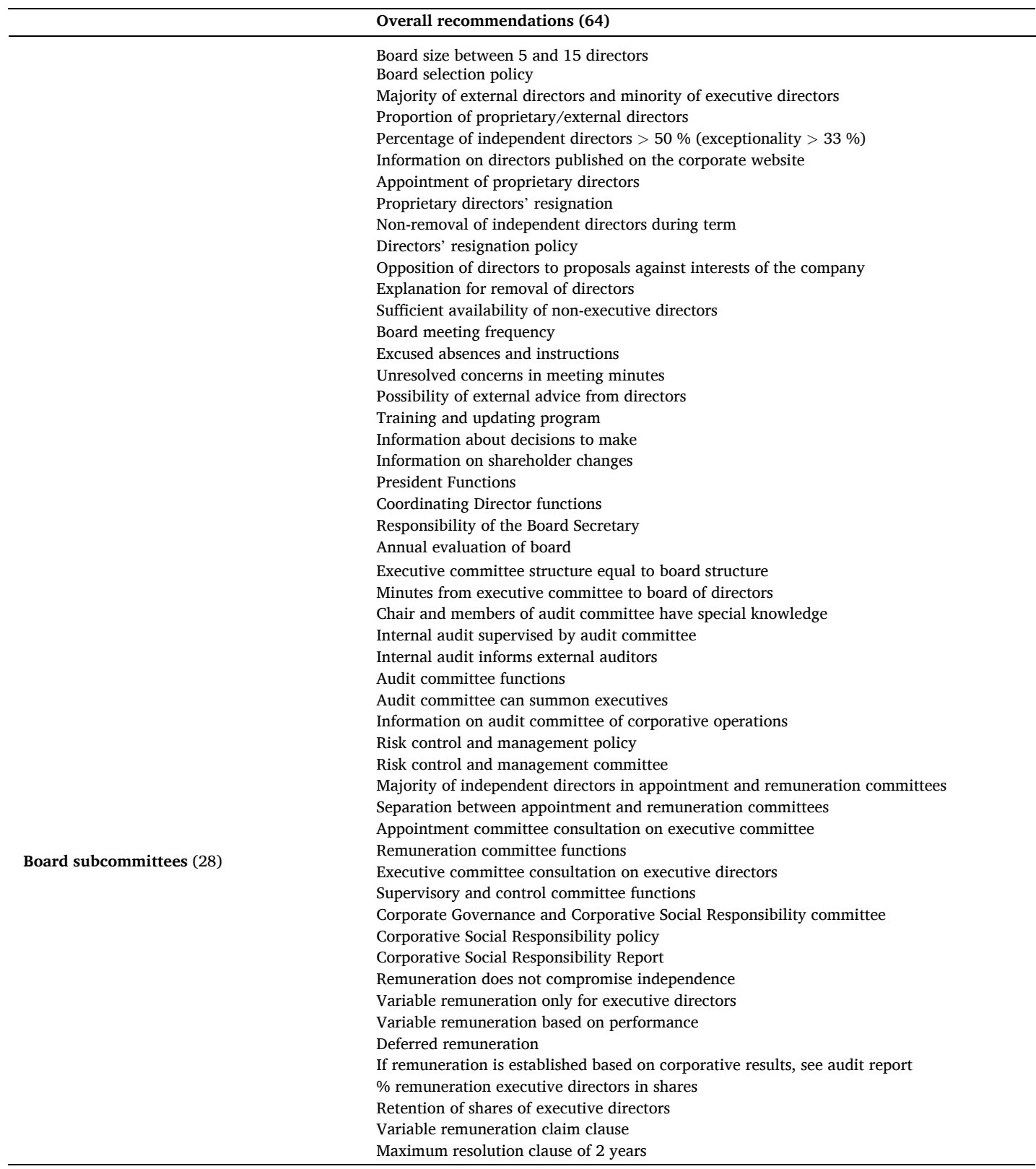

\section{Appendix B. Supplementary data}

Supplementary material related to this article can be found, in the online version, at doi:https://doi.org/10.1016/j.ribaf.2020. 101344.

\section{References}

Abdullah, S.N., 2006. Board structure and ownership in Malaysia: the case of distressed listed companies. Corp. Gov. Int. J. Bus. Soc. 6 (5), 582-594. https://doi.org/ $10.1108 / 14720700610706072$

Acero, I., Alcalde, N., 2013. Ownership structure and board composition in a high ownership concentration context. Eur. Manag. J. 32 (4), 646-657. https://doi.org/ 10.1016/j.emj.2013.10.003.

Adams, R.B., Ferreira, D., 2009. Women in the boardroom and their impact on governance and performance. J. Financ. Econ. 94 (2), 291-309. https://doi.org/ 10.1016/j.jfineco.2008.10.007. 
Adams, R., Hermalin, B., Weisbach, M., 2010. The role of boards of directors in corporate governance: a conceptual framework and survey. J. Econ. Lit. 48 , 58-107. https://doi.org/10.1257/jel.48.1.58.

Aguilera, R.V., Cuervo- Cazurra, A., 2009. Codes of good governance. Corp. Gov. Int. Rev. 17 (3), 376-387. https://doi.org/10.1111/j.1467-8683.2009.00737.x.

Ahmadi, A., Nakaa, N., Bouri, A., 2018. Chief Executive Officer attributes, board structures, gender diversity and firm performance among French CAC 40 listed firms. Res. Int. Bus. Financ. 44, 218-226. https://doi.org/10.1016/j.ribaf.2017.07.083.

Akkermans, D., Van Ees, H., Hermes, N., Hooghiemstra, R., Van der Laan, G., Postma, T., Van Witteloostuijn, A., 2007. Corporate governance in the Netherlands: an overview of the application of the Tabaksblat Code in 2004. Corp. Gov. Int. Rev. 15 (6), 1106-1118. https://doi.org/10.1111/j.1467-8683.2007.00634.x.

Albu, C.N., Girbina, M.M., 2015. Compliance with corporate governance codes in emerging economies. How do Romanian listed companies "comply-or-explain? Corp. Gov. Int. J. Bus. Soc. 15 (1), 85-107. https://doi.org/10.1108/CG-07-2013-0095.

Altman, E.I., 1968. Financial ratios, discriminant analysis and the prediction of corporate bankruptcy. J. Finance 23 (4), 589-609. https://doi.org/10.2307/2978933. Baklouti, N., Gautier, F., Affes, H., 2016. Corporate governance and financial distress of European Commercial Banks. J. Bus. Stud. Q. 7 (3), $75-96$.

Bassen, A., Prigge, S., Zöllner, C., 2009. Behind broad corporate governance aggregates: a first look at single provisions of the German corporate governance code. Corp. Ownersh. Control. 6 (3), 388-406. https://doi.org/10.22495/cocv6i3c3p4.

Beaver, W., 1966. Financial ratios as predictors of failure. J. Account. Res. (4), 71-111. https://doi.org/10.2307/2490171.

Bona-Sánchez, C., García-Meca, E., Pérez-Alemán, J., 2018. Earnings informativeness and institutional investors on boards. Rev. Contab. 21 (1), 73-81. https://doi. org/10.1016/j.rcsar.2017.09.001.

Boubaker, S., Hamza, T., Vidal-García, J., 2018. Financial distress and equity returns: a leverage-augmented three-factor model. Res. Int. Bus. Financ. 46, 1-15. https://doi.org/10.1016/j.ribaf.2016.09.003.

Bravo, F., Reguera-Alvarado, N., Pérez, M.P., 2018. The role of directors: unravelling the effects of boards on corporate outcomes. Int. J. Manag. Financ. 14 (4), 399-413. https://doi.org/10.1108/ijmf-09-2017-0200.

Brown, P., Beekes, W., Verhoeven, P., 2011. Corporate governance, accounting and finance: a review. Account. Financ. 51 (1), 96-172. https://doi.org/10.1111/ j.1467-629x.2010.00385.x.

Campbell, K., Jerzemowska, M., Najman, K., 2009. Corporate governance challenges in Poland: evidence from "comply or explain” disclosures. Corp. Gov. Int. J. Bus. Soc. 9 (5), 623-634. https://doi.org/10.1108/14720700910998184.

Cano-Rodríguez, M., Sánchez-Alegría, S., Arenas-Torres, P., 2016. The influence of auditor's opinion and auditor's reputation on the cost of debt: evidence from private Spanish firms. La influencia de la opinión de auditoria y la reputación del auditor en el coste de la deuda: evidencia en las empresas españolas no cotizadas. Spanish J. Finance Account./Revista Española de Financiación y Contabilidad 45 (1), 32-62. https://doi.org/10.1080/02102412.2015.1111096.

Chang, C., 2009. The corporate governance characteristics of financially distressed firms: evidence from Taiwan. J. Am. Acad. Bus. 15, 125-132.

Chavez, G.A., Silva, A.C., 2009. Brazil's experiment with corporate governance. J. Appl. Corporative Finance 21 (1), 34-44. https://doi.org/10.1111/j.17456622.2009.00214.x.

Cicon, J.E., Ferris, S.P., Kammel, A.J., Noronha, G., 2012. European corporate governance: a thematic analysis of national codes of governance. Eur. Financ. Manag. 18 (4), 620-648. https://doi.org/10.1111/j.1468-036X.2010.00542.x.

Cooper, D.R., Schindler, P.S., 2003. Research Methods. Irwin, Boston, MA.

Courteau, L., Di Pietra, R., Giudici, P., Melis, A., 2017. The role and effect of controlling shareholders in corporate governance. J. Manag. Gov. 21 (3), 561-572. https://doi.org/10.1007/s10997-016-9365-1.

Cuomo, F., Mallin, C., Zattoni, A., 2016. Corporate governance codes: a review and research agenda. Corp. Gov. Int. Rev. 24 (3), 222-241. https://doi.org/10.1111/ corg. 12148.

Delgado-García, J.B., De Quevedo-Puente, E., De La Fuente-Sabaté, J.M., 2010. The impact of ownership structure on corporate reputation: evidence from Spain. Corp. Gov. Int. Rev. 18 (6), 540-556. https://doi.org/10.1111/j.1467-8683.2010.00818.x.

Detthamrong, U., Chancharat, N., Vithessonthi, C., 2017. Corporate governance, capital structure and firm performance: evidence from Thailand. Res. Int. Bus. Financ. 42, 689-709. https://doi.org/10.1016/j.ribaf.2017.07.011.

Dowell, G.W.S., Shackell, M.B., Stuart, N.V., 2011. Boards, CEOs, and surviving a financial crisis: evidence from the internet shakeout. Strateg. Manage. J. 32, 1025-1045. https://doi.org/10.1002/smj.923.

Duh, M., 2017. Corporate Governance Codes and their role in improving corporate governance practice. Corporate Governance and Strategic Decision Making. https://doi.org/10.5772/intechopen.69707.

Fama, E., Jensen, M., 1983. Separation of ownership and control. J. Law Econ. 26 (2), 301-325. https://doi.org/10.1086/467037.

Fernández-Rodríguez, E., Gómez-Ansón, S., Cuervo-García, Á., 2004. The stock market reaction to the introduction of best practices codes by Spanish firms. Corp. Gov. Int. Rev. 12 (1), 29-46. https://doi.org/10.1111/j.1467-8683.2008.00692.x.

Fich, E., Slezak, S., 2008. Can corporate governance save distressed firms from bankruptcy? An empirical analysis. Rev. Quant. Financ. Account. 30 (2), 225-251. https://doi.org/10.1007/s11156-007-0048-5.

Fombrun, C.J., Ponzi, L.J., Newburry, W., 2015. Stakeholder tracking and analysis: the RepTrak ${ }^{\circledR}$ system for measuring corporate reputation. Corp. Reput. Rev. 18 (1), 3-24. https://doi.org/10.1057/crr.2014.21.

Galbreath, J., 2018. Do boards of directors influence corporate sustainable development? An attention based analysis. Bus. Strategy Environ. 27 (No. 6), 742-756. https://doi.org/10.1002/bse.2028.

García-Castro, R., Ariño, M.A., Canela, M.A., 2010. Does social performance really lead to financial performance? Accounting for Endogeneity. J. Bus. Ethics 92, 107-126. https://doi.org/10.1007/s10551-009-0143-8.

Goncharov, I., Werner, J.R., Zimmermann, J., 2006. Does compliance with the German corporate governance code have an impact on stock valuation? An empirical analysis. Corp. Gov. Int. J. Bus. Soc. 14 (5), 432-445. https://doi.org/10.1111/j.1467-8683.2006.00516.x.

Grice, J.S., Dugan, M.T., 2001. The limitations of bankruptcy prediction models: some cautions for the researcher. Rev. Quant. Financ. Account. 17 (2), 151-166. https://doi.org/10.1023/a:1017973604789.

Habib, A., Costa, M.D., Huang, H.J., Bhuiyan, M.B.U., Sun, L., 2020. Determinants and consequences of financial distress: review of the empirical literature. Account. Financ. 60, 1023-1075. https://doi.org/10.1111/acfi.12400.

Haji, A.A., Mubaraq, S., 2015. The implications of the revised code of corporate governance on firm performance. A longitudinal examination of Malaysian listed companies. J. Account. Emerg. Econ. 5 (3), 350-380. https://doi.org/10.1108/JAEE-11-2012-0048.

Hamid, M.A., Ting, I.W.K., Kweh, Q.L., 2016. The relationship between corporate governance and expropriation of minority shareholders' interests. Procedia Econ. Financ. 35, 99-106. https://doi.org/10.1016/s2212-5671(16)00014-9.

Hillman, A., Dalziel, T., 2003. Boards of directors and firm performance: integrating agency and resource dependence perspectives. Acad. Manag. Rev. 28 (3), 383-396. https://doi.org/10.5465/amr.2003.10196729.

Hooghiemstra, R., van Ees, H., 2011. Uniformity as response to soft law: evidence from compliance and non-compliance with the Dutch corporate governance code. Regul. Gov. 5 (4), 480-498. https://doi.org/10.1111/j.1748-5991.2011.01118.x.

Huse, M., Solberg, A.G., 2006. Gender-related boardroom dynamics: how Scandinavian women make and can make contributions on corporate boards. Women Manag. Rev. 21 (2), 113-130. https://doi.org/10.1108/09649420610650693.

Husein, M.F., Pambekti, G.T., 2015. Precision of the models of Altman, Springate, Zmijewski, and Grover for predicting the financial distress. J. Econ. Bus. Account. Ventur. 17 (3), 405-416. https://doi.org/10.14414/jebav.v17i3.362.

Jain, T., Jamali, D., 2016. Looking inside the black box: the effect of corporate governance on corporate social responsibility. Corp. Gov. Int. Rev. 24 (3), $253-273$. https://doi.org/10.1111/corg.12154.

Jain, A., Leka, S., Zwetsloot, G., 2011. Corporate social responsibility and phycological risk management in Europe. J. Bus. Ethics 101 (4), 619-633. https://doi.org/ 10.1007/s10551-011-0742-z. 
Javed, M., Rashid, M.A., Hussain, G., Ali, H.Y., 2020. The effects of corporate social responsibility on corporate reputation and firm financial performance: moderating role of responsible leadership. Corp. Soc. Responsib. Environ. Manag. 27 (3), 1395-1409. https://doi.org/10.1002/csr.1892.

Jensen, M., Meckling, W., 1976. Theory of the firm: managerial behavior, agency cost and ownership structure. J. Financ. Econ. 3, 305-360. https://doi.org/10.1016/ 0304-405x(76)90026-X

Kabbach de Castro, L.R., Aguilera, R.V., Crespí-Cladera, R., 2017. Family firms and compliance: reconciling the conflicting predictions within the socioemotional wealth perspective. Fam. Bus. Rev. 30 (2), 137-159. https://doi.org/10.1177/0894486516685239.

Karamanou, I., Vafeas, N., 2005. The association between corporate boards, audit committees, and management earnings forecasts: an empirical analysis. J. Account. Res. 43 (3), 453-486. https://doi.org/10.1111/j.1475-679x.2005.00177.x.

Kaspereit, T., Lopatta, K., Zimmermann, J., 2015. Does compliance with the German Corporate Governance Code pay off? An investigation of the implied cost of capital. J. Risk. Finance 16 (3), 344-376. https://doi.org/10.1108/JRF-10-2014-0150.

Kaspereit, T., Lopatta, K., Onnen, D., 2017. Shareholder value implications of compliance with the German Corporate Governance Code. Manager. Decis. Econ. 38 (2), 166-177. https://doi.org/10.1002/mde.2750.

Kiel, G.C., Nicholson, G.J., 2003. Board composition and corporate performance: how the Australian experience informs contrasting theories of corporate governance. In: Board Composition and Corporate Performance, Vol. 11, pp. 189-205. https://doi.org/10.1111/1467-8683.00318, 3.

Klein, A., 2002. Audit committee, board of director characteristics, and earnings management. J. Account. Econ. 33 (3), 375-400. https://doi.org/10.1016/s01654101(02)00059-9.

La Porta, R., Lopez-de-Silanes, F., Shleifer, A., 1999. Corporate ownership around the world. J. Finance 54 (No. 2), 471-517. https://doi.org/10.1111/00221082.00115.

La Porta, R., López-de-Silanes, F., Schleifer, A., Vishny, R., 2000. Investor protection and corporate governance. J. Financ. Econ. 58 (1), 3-27. https://doi.org/ 10.1016/s0304-405x(00)00065-9.

Larcker, D.F., Rusticus, T.O., 2010. On the use of instrumental variables in accounting research. J. Account. Econ. 49 (3), 186-205. https://doi.org/10.1016/j. jacceco.2009.11.004.

Lee, T., Yeh, Y., 2004. Corporate governance and financial distress. Evidence from Taiwan. Corp. Gov. Int. J. Bus. Soc. 12, 378-388. https://doi.org/10.1111/j.14678683.2004.00379.x.

Lee, J.E., Glasscock, R., Park, M.S., 2017. Does the ability of operating cash flows to measure firm performance improve during periods of financial distress? Account. Horiz. 31, 23-35. https://doi.org/10.2308/acch-51594.

Li, H.X., Wang, Z.J., Deng, X.L., 2008. Ownership, independent directors, agency costs and financial distress: evidence from Chinese listed companies. Corp. Gov. Int. J. Bus. Soc. 8, 622-636. https://doi.org/10.1108/14720700810913287.

Li, J., Zhao, F., Chen, S., Jiang, W., Liu, T., Shi, S., 2017. Gender diversity on boards and firms' environmental policy. Bus. Strategy Environ. 26 (3), 306-315. https:// doi.org/10.1002/bse.1918.

Luo, Y., Salterio, S.E., 2014. Governance quality in a "comply or explain” Governance Disclosure Regime. Corporative Govern. Int. Rev. 22 (No. 6), 460-481. https:// doi.org/10.1111/corg.12072.

Mahoney, D., Shuman, S., 2003. The corporate governance committee. In: The Corporate Governance Advisor, Vol. 11, pp. 32-34, 5.

Mangena, M., Chamisa, E., 2008. Corporate governance and incidence of listing suspension by the JSE Securities Exchange of South Africa: an empirical analysis. Int. J. Account. 43 (1), 28-44. https://doi.org/10.1016/j.intacc.2008.01.002.

Mangena, M., Priego, A.M., Manzaneque, M., 2020. Bank power, block ownership, boards and financial distress likelihood: an investigation of Spanish listed firms. J. Corp. Financ. 64, 1-22. https://doi.org/10.1016/j.jcorpfin.2020.101636.

Manzaneque, M., 2006. Caracterización y predicción de los desenlaces del fracaso empresarial" (Doctoral thesis). Facultad de Ciencias Sociales, Universidad de Castilla-La Mancha, Spain.

Manzaneque, M., Priego, A., Merino, E., 2016a. Corporate governance effect on financial distress likelihood: evidence from Spain. Revista de Contabilidad- Spanish Account. Rev. 19 (1), 111-121. https://doi.org/10.1016/j.rcsar.2015.04.001.

Manzaneque, M., Merino, E., Priego, A.M., 2016b. The role of institutional shareholders as owners and directors and the financial distress likelihood. Evidence from a concentrated ownership context. Eur. Manag. J. 34 (4), 439-451. https://doi.org/10.1016/j.emj.2016.01.007.

McCahery, J.A., Sautner, Z., Starks, L.T., 2016. Behind the scenes: the corporate governance preferences of institutional investors. J. Finance 71 (6), $2905-2932$. https://doi.org/10.1111/jofi.12393.

Mcknight, P.J., Weir, C., 2009. Agency costs, corporate governance mechanisms and ownership structure in large UK publicly quoted companies: a panel data analysis. Q. Rev. Econ. Financ. 49 (2), 139-158. https://doi.org/10.1016/j.qref.2007.09.008.

Mselmi, N., Lahiani, A., Hamza, T., 2017. Financial distress prediction: the case of french small and medium-sized firms. Int. Rev. Financ. Anal. 50 (2017), 67-80. https://doi.org/10.1016/j.irfa.2017.02.004.

Neifar, S., Jarboiu, A., 2018. Corporate governance and operational risk voluntary disclosure: evidence from Islamic banks. Res. Int. Bus. Financ. 46, 43-54. https:// doi.org/10.1016/j.ribaf.2017.09.006.

Odriozola, M.D., Baraibar-Diez, E., 2017. Is corporate reputation associated with quality of CSR reporting? Evidence from Spain. Corp. Soc. Responsib. Environ. Manag. 24 (2), 121-132. https://doi.org/10.1002/csr.1399.

Orazalin, N., 2019. Board gender diversity, corporate governance, and earnings management. Gend. Manag. Int. J. 35 (1), 37-60. https://doi.org/10.1108/gm-032018-0027.

Parker, S., Peters, G., Turetsky, H., 2002. Corporate Governance and corporate failure: survival analysis. Corp. Gov. Int. J. Bus. Soc. 2 (2), 4-12. https://doi.org/ 10.1108/14720700210430298.

Pindado, J., Rodrigues, L., de la Torre, C., 2008. Estimating financial distress likelihood. J. Bus. Res. 61 (9), 995-1003. https://doi.org/10.1016/j. jbusres.2007.10.006.

Pugliese, A., Bezemer, P., Zattoni, A., Huse, M., Van den Bosch, F., Volberda, H., 2009. Boards of directors' contribution to strategy: a literature review and research agenda. Corp. Gov. Int. Rev. 17 (3), 292-306. https://doi.org/10.1111/j.1467-8683.2009.00740.x.

Rahmat, M.M., Iskandar, T.M., Saleh, N.M., 2009. Audit committee characteristics in financially distressed and non-distressed companies. Manag. Audit. J. 24 (7), 624-638. https://doi.org/10.1108/02686900910975350.

Reddy, R., Locke, S., Scrimgeour, F., 2010. The efficacy of principle-based corporate governance practices and firm financial performance: an empirical investigation. Int. J. Manag. Financ. 6 (3), 190-219. https://doi.org/10.1108/17439131011056224.

Renders, A., Gaeremynck, A., 2012. Corporate governance, principal-principal agency conflicts, and firm value in European listed companies. Corp. Gov. Int. Rev. 20 (2), 125-143. https://doi.org/10.1111/j.1467-8683.2011.00900.x.

Richardson, G., Lanis, R., Taylor, G., 2015b. Financial distress, outside directors and corporate tax aggressiveness spanning the global financial crisis: an empirical analysis. J. Bank. Financ. 52, 112-129. https://doi.org/10.1016/j.jbankfin.2014.11.013.

Rodríguez-Fernández, M., 2016. Social responsibility and financial performance: the role of good corporate governance. Brq Bus. Res. Q. 19 (April-June (2)), 137-151. https://doi.org/10.1016/j.brq.2015.08.001.

Rose, C., 2016. Firm performance and comply or explain disclosure in corporate Governance. Eur. Manag. J. 34, 202-222. https://doi.org/10.1016/j. emj.2016.03.003.

Ruzaidah, R., Takiah, M.I., 2004. The Effectiveness of Audit Committee in Monitoring the Quality of Corporate Reporting" A Chapter in Corporate Governance: An International Perspective. MICG Publication, pp. 154-175.

Salloum, C.C., Azoury, N.M., Azzi, T.M., 2013. Board of directors' effects on financial distress evidence of family owned businesses in Lebanon. Int. Entrep. Manag. J. 9 (1), 59-75. https://doi.org/10.1007/s11365-011-0209-9.

Salloum, C., Azzi, G., Gebrayel, E., 2014. Audit committee and financial distress in the Middle East context: evidence of the Lebanese financial institutions. Int. Strateg. Manag. Rev. 2 (1), 39-45. https://doi.org/10.1016/j.ism.2014.09.001. 
Sánchez, J.L.F., Sotorrío, L.L., 2007. The creation of value through corporate reputation. J. Bus. Ethics 76 (No. 3), 335-346. https://doi.org/10.1007/s10551-0069285-0.

Shahwan, T.M., 2015. The effects of Corporate Governance on financial performance and financial distress: evidence from Egypt. Corp. Gov. Int. J. Bus. Soc. 15 (5), 641-662. https://doi.org/10.1108/cg-11-2014-0140.

Shivdasani, A., Yermack, D., 1999. CEO involvement in the selection of new board members: an empirical analysis. J. Finance 54 (5), 1829-1853. https://doi.org/ 10.1111/0022-1082.00168.

Shleifer, A., Vishny, R.W., 1986. Large shareholders and corporate control. J. Polit. Econ. 94 (3), 461-488. https://doi.org/10.1086/261385. Part 1.

Shleifer, A., Vishny, R.W., 1997. A survey of corporate governance. J. Finance 52 (2), 737-783. https://doi.org/10.1111/j.1540-6261.1997.tb04820.x.

Simpson, W.G., Gleason, A.E., 1999. Board structure, ownership, and financial distress in banking firms. Int. Rev. Econ. Financ. 8 (3), 281-292. https://doi.org/ 10.1016/s1059-0560(99)00026-x.

Srinidhi, B., Gul, F.A., Tsui, J., 2011. Female directors and earnings quality. Contemp. Account. Res. 28 (5), 1610-1644. https://doi.org/10.1111/j.19113846.2011.01071.x.

Steger, T., Stiglbauer, M., 2016. The German corporate governance code and its adoption by listed SMEs-just another 'procrustes bed'? Probl. Perspect. Manag. (14), 494-503. Iss. 3 (contin. 2).

Stiglbauer, M., 2010. Transparency and disclosure on corporate governance as a key factor of companies' success: a simultaneous equations analysis for Germany. Probl. Perspect. Manag. 8 (1), 161-173.

Stiglbauer, M., Velte, P., 2014. Impact of soft law regulation by corporate governance codes on firm valuation: the case of Germany. Corp. Gov. Int. J. Bus. Soc. 14 (3), 395-406. https://doi.org/10.1108/cg-05-2012-0043.

Tykvová, T., Borell, M., 2012. Do private equity owners increase risk of financial distress and bankruptcy? J. Corp. Financ. 18 (1), 138-150. https://doi.org/10.1016/ j.jcorpfin.2011.11.004.

Udin, S., Arshad, M., Javid, A.J., 2017. The effects of ownership structure on likelihood of financial distress: an empirical evidence. Corp. Gov. Int. J. Bus. Soc. 17 (4), 589-612. https://doi.org/10.1108/cg-03-2016-0067.

Uzun, H., Szewczyk, S.H., Varma, R., 2004. Board composition and corporate fraud. Financ. Anal. J. 60 (3), 33-43. https://doi.org/10.2469/faj.v60.n3.2619.

Wang, Z.J., Deng, X.L., 2006. Corporate governance and financial distress: evidence from Chinese listed companies. Chinese Econ. 39 (5), 5-27. https://doi.org/ 10.2753/ces1097-1475390501.

Weber, S.C., Velte, P., 2011. Betriebswirtschaft-der zusammenhang zwischen corporate governance und kapitalkosten des unternehmens. Deutsches Steuerrecht 49 (1), 39-45.

Zattoni, A., Cuomo, F., 2010. How independent, competent and incentivized should non-executive directors be? An empirical investigation of good governance codes. Br. J. Manag. 21 (1), 63-79. https://doi.org/10.1111/j.1467-8551.2009.00669.x.

Zmijewski, M.E., 1984. Methodological issues related to the estimation of financial distress prediction models. J. Account. Res. 22, 59-82. https://doi.org/10.2307/ 2490859. 